\title{
Listening with Pauline in Belfast
}

\section{IONE}

"Babies are the best listeners!"

Listening back, I hear Pauline repeating one of her own well-known quotes as she settled in to begin writing her keynote address for the Just Improvisation conference organized by Sara Ramshaw and Paul Stapleton and held May 29-30, 2015 at the Sonic Arts Research Centre, Queen's University Belfast.

Pauline and I were excited to be going to Belfast. The title and scope of the conference were intriguing and seemed perfectly designed for us to experience together. The themes resonated with our thirty years of facilitating Deep Listening ${ }^{\circledR}$ retreats and nurturing Deep Listening ${ }^{\circledR}$ artists, as well as my own private work with women and men as a psychotherapist and teacher of Women's Mysteries.

In her own childhood in Houston, Texas, Pauline was steeped in the sounds of her mother and grandmother's piano students' playing and both lulled and stimulated by the rich tapestry of Houston's insect and animal environment. The child that she was never forgot the internalized lessons of that time. They grew into a living philosophy of Deep Listening ${ }^{\circledR}$ that she spread throughout the world. She particularly loved to commune with children through sound.

The conference gave us food for thought as well as rich creative pleasures. A musical interlude included a large community of artists who performed together, as well as sterling solo performances by Okkyung Lee and Maria Chavez (whose musicianship had been championed by Pauline since Maria's youthful years in Houston).

Pauline and I were heartened to listen to friend and colleague, Professor of Ethnomusicology Dr. Ellen Waterman, as she delivered her discerning keynote, "The Audibility of Difference." Ellen also chaired the lively plenary discussion, "Imagining the Future."

There was much joy among us over lunches and dinners external to, but of course a part of, the conference - especially since three of us, Pauline, Maria and I, had birthdays that were close to the conference date (Pauline turned 83 on May 30, 2015).

In her keynote address, Pauline asked, "Can we make our listening a safe zone, a place where the children of the world will feel safe to play?"

I must say that the environment of the conference itself answered her question in ways both harmonious and surprising. The challenges of interaction between communities usually considered separate were overcome through allowing our own improvisatory skills to come into "play."

Child and family advocates-judges, lawyers and therapists-were in the same room with artists and musicians of all kinds. We were all curious about each other. We had all experienced our own families. Most importantly, we had all been children.

Most memorable to us, perhaps, is the fact that Pauline and I-along with the other artists among us-were introduced to the worlds of child protection advocates in Belfast.

We learned of the restrictions and challenges of existing legal systems and witnessed the deep caring of the participants for the children and families in their care. There was the realization that these men and women who were attempting to justly assess and support the needs of children and families were truly warriors of a special kind.

By the end of the day, there were special smiles, and these "warriors" expressed to us how pleased they were to be at the conference and to be able to speak of their daily challenges to our group. They indicated that they rarely, if ever, had such a forum for their thoughts and feelings. Truly, it was clear, they were appreciating being listened to.

Here, it was "safe to play." 